Studia i Materiały, 2/2016 (22), cz. 2: 257-269

\title{
Wynagrodzenia pielęgniarek w Polsce w latach 2010-2014
}

\author{
Zofia Skrzypczak*, Józef Haczyński**
}

\begin{abstract}
Wynagrodzenia pielegniarek od lat budza kontrowersje. Celem niniejszego opracowania jest analiza zmian poziomu wynagrodzeń pielegniarek $w$ Polsce $w$ latach 2010-2014, przeprowadzona na bazie dostepnych danych statystycznych. W analizowanym okresie tempo wzrostu wynagrodzeń pielęgniarek byto najniższe, zarówno w porównaniu z przeciętnymi płacami osób pracujacych $w$ podmiotach gospodarczych zatrudniajacych powyżej 9 osób, jak i ptacami pracowników pozostatych zawodów medycznych. Po uwzględnieniu stopy inflacji zaobserwowano w latach 2010-2014 spadek ptacy realnej pielegniarek o 2,3\%.

Dane pochodzace z różnych źródet pokazuja istotne różnice poziomu średniej ptacy brutto pielegniarek. Konieczne jest zatem przeprowadzenie kompleksowych $i$ wiarygodnych badan dotyczacych wynagrodzeń pracowników stużby zdrowia.
\end{abstract}

Słowa kluczowe: wynagrodzenia pielęgniarek, przeciętna płaca.

Nadesłany: 10.11.2016 | Zaakceptowany do druku: 22.12.2016

\section{Nurses Wages in Poland in 2010-2014}

Nurses wages are controversial for years. The aim of the study was to analyze changes in the level of nurses wages in Poland in 2010-2014 based on available statistical data. In the analyzed period, the nurses salaries growth rate was the lowest, both in comparison with the average wages of people working in entities employing more than 9 persons and with wages of employees of other medical professions. After taking into account the inflation rate, $2.3 \%$ of decline in real nurses wages was observed in 2010-2014.

Data from different sources show significant differences in the level of average nurses gross wages. It is therefore necessary to conduct comprehensive and reliable study on the salaries of workers in medical profession in Poland.

Keywords: nurses salery, nurses wages, average wage.

Submitted: 10.11.2016 | Accepted: 22.12.2016

JEL: I14, I39

\footnotetext{
"Zofia Skrzypczak - doc. dr, Wydział Zarządzania, Uniwersytet Warszawski.

Adres do korespondencji: Wydział Zarządzania, Uniwersytet Warszawski, ul Szturmowa 1/3, 02-678 Warszawa, e-mail: skrzypczak@wz.uw.edu.pl.

** Józef Haczyński - dr hab. nauk med., Wydział Zarządzania, Uniwersytet Warszawski. Adres do korespondencji: Wydział Zarządzania, Uniwersytet Warszawski, ul Szturmowa 1/3, 02-678 Warszawa, e-mail: jhaczynski@wz.uw.edu.pl.
} 


\section{Wprowadzenie}

Koszty zapewnienia nowoczesnej opieki zdrowotnej wykazują stałą tendencję wzrostową, co w znaczny sposób obciąża finansowo zarówno budżet państwa, jak i samych obywateli. Jedną z istotnych składowych tych kosztów są wydatki związane $\mathrm{z}$ wynagrodzeniami pracowników sektora ochrony zdrowia. Wynagrodzenia pracowników służby zdrowia w Polsce od wielu lat wywołują duże emocje wśród samych zainteresowanych, kadry zarządzającej w ochronie zdrowia, a także w samym społeczeństwie. Służba zdrowia w Polsce boryka się z wieloletnim narastającym niedofinansowaniem, co w oczywisty sposób przekłada się na poziom płac pracowników tego sektora. Pielęgniarki stanowią największą grupę zawodową w polskim systemie opieki zdrowotnej. Zawody pielęgniarki i położnej są samodzielnymi zawodami medycznymi, których istotą jest udzielanie świadczeń zdrowotnych, a także nauczanie zawodu, prowadzenie prac naukowo-badawczych, kierowanie i zarządzanie zespołami pielęgniarek i położnych oraz praca na innych stanowiskach związanych z udzielaniem świadczeń zdrowotnych (zob. Ustawa z dnia 15 lipca 2011 roku o zawodach pielęgniarki i położnej).

Wysokość wynagrodzeń pielęgniarek i położnych ustalana jest przez pracodawcę, co zostało potwierdzone w odpowiedzi Sekretarza Stanu w Ministerstwie Zdrowia na interpelację poselską dotycząca wynagrodzeń w tej grupie zawodowej (Interpelacja $n r 29353$ w sprawie wysokości pensji..., 2014). W Polsce większość pielęgniarek zatrudniona jest $\mathrm{w}$ podmiotach leczniczych, a więc za ustalenie stawek ich wynagrodzeń są odpowiedzialni kierownicy tych podmiotów. Wysokość wynagrodzeń zależy w dużej mierze od kondycji finansowej podmiotów leczniczych, dostępnych środków finansowych, a także od sytuacji na lokalnym rynku pracy. $\mathrm{Z}$ powodu znacznej liczebności tej grupy zawodowej wynagrodzenia pielęgniarek mają istotny wpływ na stan budżetu podmiotów leczniczych. Dla wielu instytucji najprostszym i najszybszym sposobem utrzymania równowagi finansowej może być bezpośrednio - zmniejszenie liczby zatrudnionych pielęgniarek, lub pośrednio - w wyniku restrukturyzacji placówki ochrony zdrowia, redukcji liczby łóżek, ograniczenia przyj- mowania pacjentów, scalania oddziałów lub zmiany modelu opieki zdrowotnej z przesunięciem w kierunku opieki ambulatoryjnej (Alameddine i in., 2012). W obu przypadkach dochodzi do nałożenia większej ilości obowiązków na pozostały personel. Charakter obowiązków pielęgniarek wymaga od nich pracy w charakterze zmianowym i pełnienia dyżurów również $w$ dni wolne od pracy czy święta. Dodatkowo, w związku ze zmianami w ochronie zdrowia, zmieniaja się również pozycja i rola pielęgniarek, a co za tym idzie zwiększa się zakres ich obowiązków zawodowych, pojawiają się zbiurokratyzowane procedury pracy, takie jak np. możliwość wystawiania recept. Po stronie popytowej rynku pracy pielęgniarek rośnie liczba potencjalnych pracodawców (na przykład szpitali, długoterminowych zakładów opieki, przychodni), co przy ograniczonej podaży oznacza, iż konkurują one o zatrudnienie pielęgniarek posiadających różne specjalności i wysokie umiejętności.

W Polsce zawód pielęgniarek jest zdominowany przez kobiety, które stanowią ponad $98 \%$ wszystkich pracowników w tym zawodzie (Zabezpieczenie spoteczeństwa, 2015). Kobiety w naszej kulturze odgrywają ważną rolę w rodzinie, zajmując się m.in. wychowaniem dzieci czy też obowiązkami domowymi. Te dodatkowe i często istotne obowiązki pozazawodowe mogą być przyczyną przewlekłego przemęczenia, prowadzić do długotrwałego stresu czy szybszego wypalenia zawodowego $\mathrm{w}$ tej grupie pracowników.

Powyższe czynniki oraz rosnące ceny dóbr i usług konsumpcyjnych mają niewątpliwie wpływ na oczekiwania finansowe tej grupy zawodowej.

Niemal co roku jesteśmy świadkami różnych form manifestowania niezadowolenia pielęgniarek i położnych, wynikającego z ich przeświadczenia o stosunkowo niskich wynagrodzeniach. Protesty i strajki są próbą wymuszenia podwyżek i zmiany polityki wynagrodzeń poprzez lepsze dostosowanie pensji pielęgniarek do rodzaju wykonywanej pracy i ponoszonej odpowiedzialności. Przeświadczenie o niskim poziomie wynagrodzenia pielęgniarek i położnych nie dotyczy tylko pracowników tej grupy zawodowej w naszym kraju, lecz również pracujących w krajach o znacznie wyższym PKB. Z badań przeprowadzonych w USA wśród pielęgniarek wynika, że większość ankietowanych uważała, iż otrzymy- 
wały one zbyt niskie wynagrodzenie w stosunku do obciążenia zawodowego. Niewiele $\mathrm{z}$ nich zdecydowało się jednak na zmianę zawodu (Hader, 2010).

Pielęgniarki to profesja medyczna ciesząca się dużym zaufaniem społeczeństwa w Polsce. Badania CBOS, przeprowadzone w dniach 1-12 sierpnia 2013 roku na liczącej 904 osoby reprezentatywnej próbie losowej dorosłych mieszkańców Polski wykazały, iż w społecznej hierarchii prestiżu różnych zawodów na 6. miejscu (przed nauczycielem i lekarzem, a po profesorze uniwersytetu) znalazł się zawód pielęgniarki (Prestiż, 2013). Pomimo tak dużego prestiżu społecznego względy ekonomiczne i charakter pracy powodują, że zawód pielęgniarki i położnej w Polsce przestaje być atrakcyjnym wyborem dla młodych ludzi, czego wskaźnikiem jest zmniejszająca się liczba studentów kierunków pielęgniarstwa. Konsekwencją tego faktu jest wzrost średniego wieku pielęgniarek. O ile w 2008 roku przeciętny wiek pielegniarki wynosił niewiele ponad 44 lata, o tyle na koniec 2014 roku średnia wieku dla tej grupy zawodowej wzrosła o ok. 4,5 roku i osiągnęła poziom 48,5 lat. Prawie połowa pielęgniarek pracujacych w Polsce to osoby powyżej 50. roku życia. Najmniej liczną grupę stanowią pielęgniarki w wieku 21-25 lat, których jest ok. 1,5\%. Miernikiem tzw. prostej zastępowalności pokoleń jest relacja odsetka pracowników najstarszych do najmłodszych. Udział w populacji pielęgniarek w wieku powyżej 65 roku życia jest pięciokrotnie wyższy od udziału w populacji pielęgniarek z najmłodszej grupy wiekowej, a zatem w zawodzie pielęgniarek w Polsce brak prostej zastępowalności pokoleniowej (Centralny Rejestr, 2016).

Jednym ze sposobów zniwelowania niedoborów kadrowych w zawodzie pielęgniarek może być odpowiednie kształtowanie polityki wynagrodzeń, a więc lepsze dostosowanie płac pielęgniarek do rodzaju wykonywanej pracy i ponoszonej odpowiedzialności. W ostatnim okresie pojawiło się wiele opracowań i raportów dotyczących wynagrodzeń pracowników służby zdrowia (Cichońska, 2015; Hajec, 2015; Poręba, 2016). Brakuje jednak kompleksowego spojrzenia na poziom wynagrodzeń pielęgniarek, wykorzystania najnowszych dostępnych danych GUS oraz uwzględnienia wpływu inflacji na sytuację materialną pielęgniarek.
Celem niniejszej pracy jest analiza zmian poziomu wynagrodzeń pielęgniarek w Polsce w latach 2010-2014. Na potrzeby opracowania dokonano szczegółowych porównań średnich płac pielegniarek oraz pracowników zatrudnionych w podmiotach gospodarczych, z uwzględnieniem podziału zatrudnionych według stażu pracy oraz wieku. Zmiany zachodzace w poziomie średnich wynagrodzeń $\mathrm{w}$ analizowanym okresie zestawiono $\mathrm{z}$ tempem wzrostu cen dóbr i usług konsumpcyjnych, aby poznać kierunki zmian siły nabywczej otrzymywanych przez pracowników wynagrodzeń.

Część badawcza prezentowanej pracy została oparta przede wszystkim na wynikach badań przeprowadzanych co 2 lata przez Główny Urząd Statystyczny na grupie podmiotów gospodarczych zatrudniających ponad 9 osób. Rezultaty tych ustaleń publikowane są w cyklicznie publikowanym opracowaniu Struktura wynagrodzeń wedtug zawodów. Szczegółowe dane o poziomie przecietnych wynagrodzeń brutto pracowników różnych zawodów Główny Urząd Statystyczny gromadzi i prezentuje jedynie dla podmiotów gospodarczych zatrudniających powyżej 9 osób, bowiem podmioty zatrudniające mniejszą liczbę osób nie mają obowiązku podawania informacji o wysokości wynagrodzeń zatrudnianych pracowników.

\section{Wynagrodzenie pielęgniarek na tle przeciętnego wynagrodzenia w gospodarce narodowej}

W tabeli 1 zestawiono poziomy przeciętnych miesięcznych wynagrodzeń brutto ustalonych dla:

- zatrudnionych w gospodarce narodowej,

- pracujących w podmiotach gospodarczych zatrudniających powyżej 9 osób (pozycja sygnowana jako „ogółem”),

- pielęgniarek pracujących w podmiotach gospodarczych zatrudniających powyżej 9 osób.

W przypadku zatrudnionych w całej gospodarce narodowej źródłem informacji o poziomie przeciętnego wynagrodzenia był Rocznik Statystyczny RP, natomiast wynagrodzenia osób pracujących w podmiotach gospodarczych zatrudniających powyżej 9 osób (w tym także pielęgniarek) ustalono, opierając się na przeprowadzanych przez Główny Urząd Statystyczny (co dwa lata) 
badaniach, których wyniki prezentowane są w cyklicznej publikacji GUS zatytułowanej Struktura wynagrodzeń wedtug zawodów.

Należy również zwrócić uwagę na fakt, że ustalenia GUS dotyczą jedynie poziomu wynagrodzenia brutto $\mathrm{Z}$ tytułu umowy o prace - jest to tzw. wynagrodzenie osobowe za pracę $\mathrm{w}$ godzinach nominalnych (wynagrodzenie zasadnicze i dodatek za pracę zmianową) oraz za prace $\mathrm{w}$ godzinach nadliczbowych. Takie dane umożliwiają jedynie pewne oszacowanie wielkości przychodów pracowników ogółem oraz przedstawicieli poszczególnych grup zawodowych (Cichońska, 2015). Ze względu na brak innych źródeł informacji o dochodach $\mathrm{z}$ pracy dalsze rozważania $\mathrm{w}$ niniejszej pracy będą jednak prowadzone na bazie pochodzących z powyżej wskazanych źródeł danych, przy pełnej świadomości ograniczoności zasobów informacji. To ograniczenie informacji dotyczy w dużym stopniu pielęgniarek - w analizach nie zostają ujęte wynagrodzenia pielęgniarek pracujących w placówkach zatrudniających 9 i mniej osób oraz nie objęte są analizą pielęgniarki zatrudnione poprzez system kontraktów.

W rozpoczynającym analizowany okres roku 2010 najniższy poziom wynagrodzenia brutto charakteryzował grupę zawodową

Tabela 1. Poziom przeciętnego miesięcznego wynagrodzenia brutto w gospodarce narodowej oraz w podmiotach gospodarczych zatrudniających powyżej 9 osób: ogółem i w grupie zawodowej pielęgniarek w latach 2010-2014 (PLN)

\begin{tabular}{|c|c|c|c|}
\hline \multirow{2}{*}{ Lata } & \multirow{2}{*}{$\begin{array}{c}\text { Gospodarka } \\
\text { narodowa* }\end{array}$} & \multicolumn{2}{|c|}{ Podmioty gospodarcze zatrudniające powyżej 9 osób** } \\
\cline { 3 - 4 } & 3224,13 & ogółem & pielęgniarki \\
\hline 2010 & 3530,47 & 3543,50 & 3186,44 \\
\hline 2012 & 3777,10 & 3895,72 & 3276,61 \\
\hline 2014 & 4107,72 & 3400,31 \\
\hline
\end{tabular}

Źródło: zestawienie własne na podstawie: Rocznik Statystyczny RP 2013 (2014). Warszawa: GUS ; Rocznik Statystyczny RP 2015 (2016). Warszawa: GUS; Struktura wynagrodzeń według zawodów w październiku 2010 (2012). Warszawa: GUS; Struktura wynagrodzeń według zawodów w październiku 2012 (2014). Warszawa: GUS; Struktura wynagrodzeń według zawodów w październiku 2014 (2016). Warszawa: GUS.

Rysunek 1. Poziom przeciętnego miesięcznego wynagrodzenia brutto w gospodarce narodowej, w podmiotach gospodarczych zatrudniających powyżej 9 osób: ogółem oraz w grupie zawodowej pielęgniarek w latach 2010-2014 (PLN)

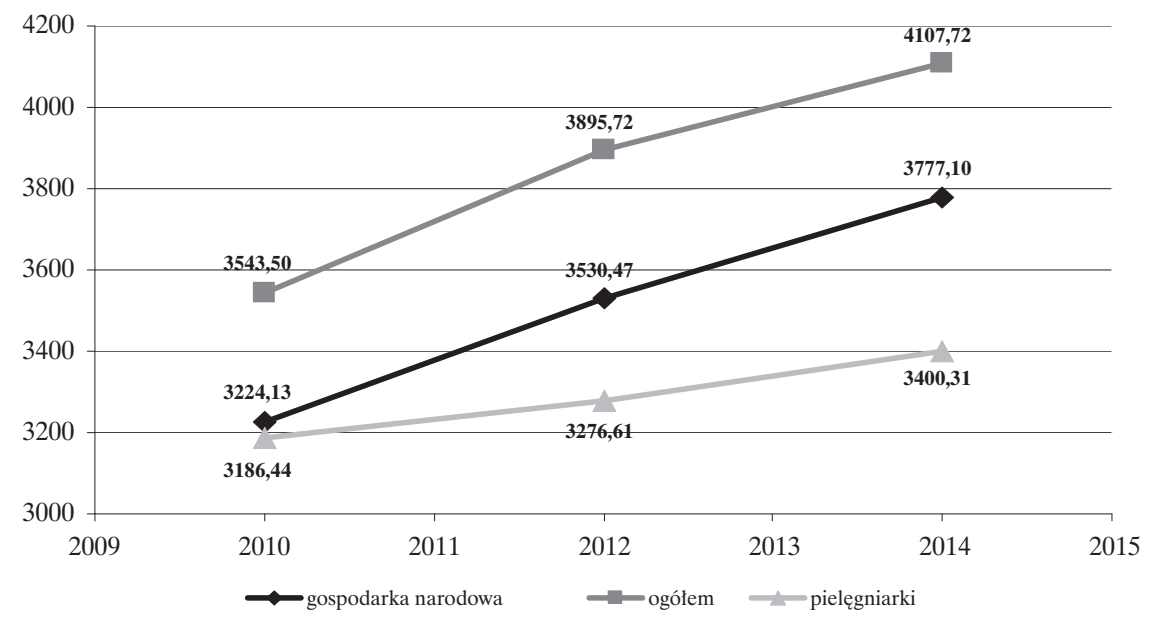

Źródło: jak w tabeli 1. 
pielęgniarek i wynosił 3186,44 PLN; niewiele wyższa była średnia płaca $\mathrm{w}$ gospodarce narodowej - 3244,13 PLN; najwyższe przeciętne wynagrodzenie brutto otrzymywal pracownik podmiotu gospodarczego zatrudniającego powyżej 9 osób - 3543,50 PLN.

W roku 2012 i 2014 nadal wynagrodzenie brutto pielęgniarek było najniższe i wynosiło odpowiednio: 3276,61 PLN i 3400,31 PLN. W tych latach średnia płaca brutto w gospodarce narodowej już znacznie przewyższała wynagrodzenie pielęgniarek i wynosiła: 3520,47 PLN w roku 2012 i 3777,10 PLN w 2014 roku.

Różnice w poziomie wynagrodzeń przeciętnego pracownika w podmiotach gospodarczych zatrudniających powyżej 9 osób i pielęgniarek też się znacznie pogłębiły.

Analiza danych przedstawionych na rysunku 1 pozwala stwierdzić, że o ile w roku 2010 przeciętne wynagrodzenie brutto w gospodarce narodowej było niewiele wyższe (o niecałe $2 \%$ ) od przeciętnego wynagrodzenia pielęgniarek, o tyle w roku 2014 ta „nadwyżka” sięgała już 11\%. Przeciętne wynagrodzenie brutto w podmiotach gospodarczych zatrudniających powyżej 9 osób było znacznie wyższe od wynagrodzenia pielęgniarek już w 2010 roku o ponad $11 \%$, a w roku 2014 o $21 \%$.

We wszystkich analizowanych grupach pracowników widoczna jest w latach 2010 2014 systematyczna tendencja wzrostowa średniej płacy; jednak w grupie zawodowej pielęgniarek tempo wzrostu wynagrodzeń było najniższe. W analizowanym okresie w tej grupie zawodowej nastąpił wzrost średniego wynagrodzenia brutto tylko o 6,7\% (z 3186,44 PLN w 2010 roku do 3400,31 PLN w 2014 roku, tj. wzrost o 213,89 PLN), wobec wzrostu średnich wynagrodzeń w całej gospodarce narodowej o ponad 17\% (z 3224,13 PLN w 2010 roku do 3777,10 PLN w 2014 roku, tj. wzrost o 552,97 PLN). W podmiotach zatrudniających powyżej 9 osób obserwowano nieco niższy wzrost o prawie $16 \%$ (z 3543,50 PLN w 2010 roku do 4107,72 PLN w 2014 roku, tj. wzrost o 564,23 PLN) .

Oceniając wzrost wynagrodzeń w pewnym okresie, należy porównać tempo wzrostu płac nominalnych $\mathrm{z}$ tempem zmian cen dóbr i usług konsumpcyjnych, czyli stopa inflacji - wtedy dopiero można mówić o rzeczywistych zmianach sytuacji materialnej pracowników, tj. o zmianach płacy realnej.

Jeżeli uwzględniony zostanie fakt, że w okresie 2010-2014 ceny dóbr i usług konsumpcyjnych wzrosły o 9,2\% (Roczne Wskaźniki Makroekonomiczne, 2016), to wzrost wynagrodzeń pielęgniarek o $6,7 \%$ oznacza praktycznie spadek ich płacy realnej o $2,3 \%$, czyli mniejszą siłę nabywczą otrzymywanych wynagrodzeń i pogorszenie warunków życia. Zjawiska tego

Rysunek 2. Tempo wzrostu wynagrodzeń oraz cen dóbr i usług konsumpcyjnych w latach 2010-2014 $(\%$, rok $2010=100)$

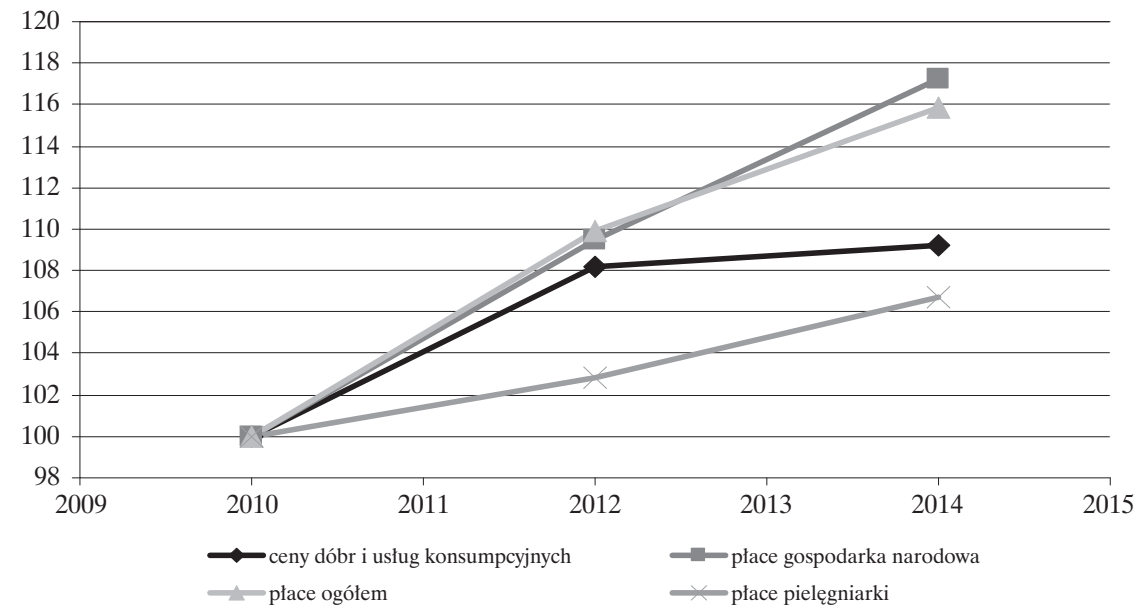

Źródło: obliczenia własne na podstawie danych z tabeli 1 oraz Roczne wskaźniki makroekonomiczne, Główny Urząd Statystyczny, http://stat.gov.pl/wskazniki-makroekonomiczne/ (12.11.2016). 
nie obserwowano w przypadku średnich wynagrodzeń w gospodarce narodowej i wynagrodzeń ogółem w podmiotach zatrudniających powyżej 9 osób. W tej grupie tempo wzrostu płac nominalnych było odpowiednio o $17 \%$ i $16 \%$ wyższe od stopy inflacji.

Szczególnie ciężkim okresem dla sytuacji bytowej pielęgniarek były lata 2010-2012. W tym czasie ich wynagrodzenie brutto wzrosło jedynie o 2,8\%, a ceny dóbr konsumpcyjnych wzrosły o $8,2 \%$, nastąpił zatem spadek płacy realnej o ok. 5\% Natomiast w latach 2012-2014 sytuacja pielęgniarek była nieco korzystniejsza, odnotowano wzrost płac pielęgniarek o $3,8 \%$ a ceny dóbr konsumpcyjnych wzrosły jedynie o $0,9 \%$, czyli nastąpił wzrost płacy realnej o $2,9 \%$.

Powyższe prezentacje zmian płacy realnej pielęgniarek uświadamiają, iż nie są bezpodstawne ich żądania wzrostu wynagrodzeń. Protesty pielęgniarek kończą się zazwyczaj podpisaniem porozumienia z ministrem zdrowia, deklarującym wzrost płac. Zgodnie z Rozporządzeniem Ministra Zdrowia z 8 września 2015 roku w sprawie ogólnych warunków umów o udzielanie świadczeń opieki zdrowotnej (Dz.U. z 2015 poz. 1400) pielęgniarki od 1 września 2015 roku otrzymały podwyżki w wysokości przeciętnie 300 PLN brutto. Kolejne negocjacje zaowocowały obietnicą zwiększenia kwot przeznaczonych na wzrost średniego miesiecznego wynagrodzenia do kwoty 400 PLN miesięcznie w okresie od 01.09.2015 r. do 31.08.2016 r. oraz w kolejnych latach: 800 PLN miesięcznie w okresie od 01.09.2016 r. do 31.08.2017 r., 1200 PLN miesięcznie od 01.09.2017 r. do 31.08.2018 r. oraz 1600 PLN miesięcznie od 01.09.2018 r. do 31.08.2019 r. (Rozporzadzenie, 2015).

W październiku 2016 roku Główny Urząd Statystyczny przeprowadził kolejne badania poziomu wynagrodzeń pracowników podmiotów gospodarczych zatrudniających powyżej 9 osób. Po opublikowaniu ich wyników można będzie ustalić, czy i na ile deklaracje decydentów przełożyły się na faktyczny wzrost poziomu wynagrodzeń pielęgniarek.

\section{Wynagrodzenie pielęgniarek na tle innych zawodów medycznych}

Aby ocenić poziom wynagrodzenia pielęgniarek w obrębie profesji medycznych, dokonano porównania przeciętnej płacy pielęgniarek oraz innych zawodów medycznych w Polsce, uzupełniając to zestawienie przeciętnym wynagrodzeniem brutto osób pracujacych w podmiotach gospodarczych zatrudniających powyżej 9 osób - pozycja „ogółem” (tabela 2 i rysunek 3 ).

Analiza danych przedstawionych na rysunku 3 pozwala na stwierdzenie, iż najwyższe przeciętne wynagrodzenie brutto wśród przedstawicieli zawodów medycznych otrzymywali lekarze. Wzrosło ono w latach 2010-2014 z poziomu ponad 6650 PLN do prawie 7050 PLN. Przeciętne miesięczne wynagrodzenie brutto diagnostów laboratoryjnych oscylowało wokół 4000 PLN (z nie-

Tabela 2. Poziom przeciętnego wynagrodzenia brutto ogótem oraz różnych zawodów medycznych w Polsce w latach 2010-2014 (PLN)

\begin{tabular}{|l|c|c|c|}
\hline & $\mathbf{2 0 1 0}$ & $\mathbf{2 0 1 2}$ & $\mathbf{2 0 1 4}$ \\
\hline Ogółem & 3543,50 & 3895,72 & 4107,72 \\
\hline Lekarze & 6663,02 & 6788,82 & 7040,55 \\
\hline Pielęgniarki & 3186,44 & 3276,61 & 3400,31 \\
\hline Położne & 3301,24 & 3232,38 & 3372,22 \\
\hline Ratownicy medyczni & 3154,67 & 2960,90 & 3854,54 \\
\hline Diagności laboratoryjni & 3827,50 & 4157,29 & 4359,05 \\
\hline
\end{tabular}

Źródło: zestawienie własne na podstawie Struktura wynagrodzeń według zawodów w październiku 2010 (2012). Warszawa: GUS; Struktura wynagrodzeń według zawodów w październiku 2012 (2014). Warszawa: GUS; Struktura wynagrodzeń według zawodów w październiku 2014 (2016). Warszawa: GUS. 
Rysunek 3. Poziom przeciętnego wynagrodzenia brutto ogółem oraz przeciętnych wynagrodzeń przedstawicieli różnych zawodów medycznych w Polsce w latach 2010-2014 (PLN)

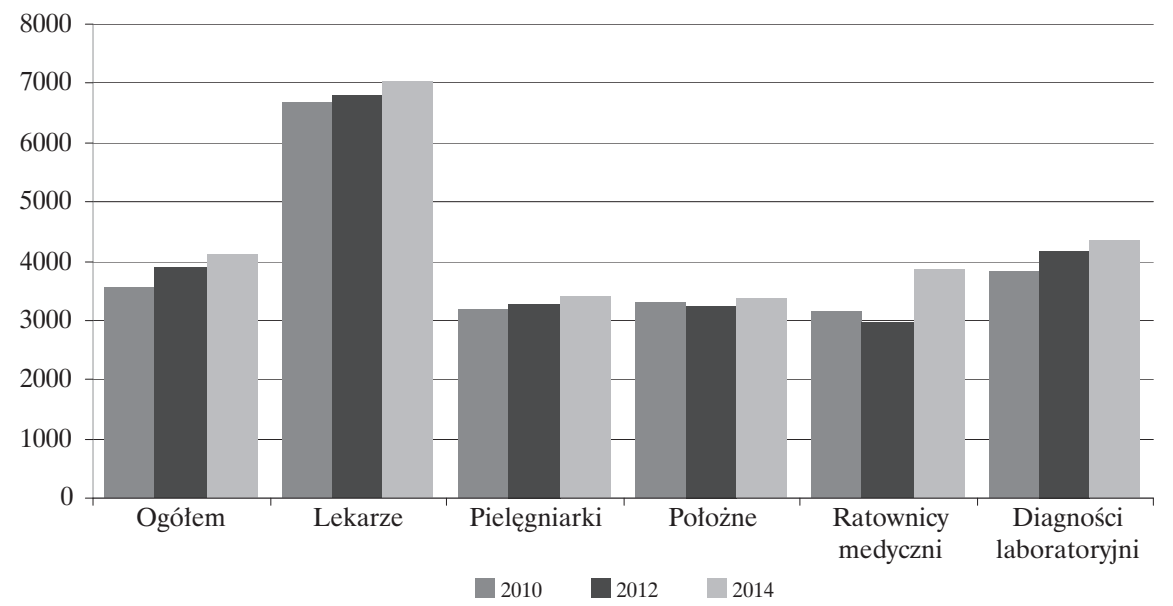

Źródło: jak w tabeli 2.

wielką tendencją wzrostową), a najniższe płace otrzymywały pielęgniarki i położne.

\section{Wynagrodzenia pielęgniarek zatrudnionych w placówkach publicznych i prywatnych}

W tabeli 3 i na rysunku 4 zestawiono przeciętne wynagrodzenia brutto osób pracujących w podmiotach gospodarczych zatrudniających powyżej 9 osób oraz przeciętne wynagrodzenia pielęgniarek, dzieląc wszystkich pracowników - według formy własności pracodawcy - na: zatrudnionych w sektorze publicznym oraz prywatnym.

Analiza danych w tabeli 3 i na rysunku 4 pozwala stwierdzić, że w omawianym okresie wszyscy zatrudnieni w sektorze publicznym otrzymywali wyższe wynagrodzenia niż zatrudnieni w sektorze prywat- nym - prawidłowość ta dotyczy również pielęgniarek. W roku 2010 wynagrodzenie brutto pieleggniarek zatrudnionych $\mathrm{w}$ sektorze publicznym było wyższe o $12 \%$, w roku 2012 o 5\% i w roku 2014 wyższe o $9,6 \%$ od płac pielęgniarek w sektorze prywatnym.

Oceniając powyższe zestawienie należy jednak mieć na uwadze fakt, że publikacja GUS, na której oparta jest analiza (Struktura wynagrodzeń, 2012, 2014, 2016) obejmuje jedynie dane o wynagrodzeniach brutto wypłacanych na podstawie umowy o prace osobom pracujaccym w podmiotach gospodarczych zatrudniających powyżej 9 osób. Ze względu na fakt, że część pielęgniarek pracuje w małych podmiotach opieki zdrowotnych zatrudniających niewielką (poniżej 9 osób) liczbę pracowników, a część pracuje na kontraktach, to fakt

Tabela 3. Poziom przeciętnego wynagrodzenia brutto osób pracujących w podmiotach gospodarczych zatrudniających powyżej 9 osób oraz pielęgniarek z uwzględnieniem podziału na zatrudnionych $w$ sektorze publicznym i prywatnym w latach 2010-2014 (w PLN)

\begin{tabular}{|l|c|c|c|c|c|c|}
\hline \multirow{2}{*}{ Sektor } & \multicolumn{2}{|c|}{2010} & \multicolumn{2}{c|}{2012} & \multicolumn{2}{c|}{2014} \\
\cline { 2 - 7 } & ogółem & pielęgniarki & ogółem & pielęgniarki & ogółem & pielęgniarki \\
\hline oba sektory & 3543,50 & 3186,44 & 3895,72 & 3276,61 & 4107,72 & 3400,31 \\
\hline publiczny & 3804,70 & 3247,83 & 4116,05 & 3309,09 & 4356,82 & 3443,79 \\
\hline prywatny & 3367,68 & 2897,64 & 3773,30 & 3126,84 & 3980,74 & 3142,68 \\
\hline
\end{tabular}

Źródło: jak w tabeli 2.

Wydział Zarządzania UW DOI 10.7172/1733-9758.2016.22.21 
Rysunek 4. Poziom przeciętnego wynagrodzenia brutto ogółem oraz pielęgniarek w sektorze publicznym i prywatnym w latach 2010-2014 (w PLN)

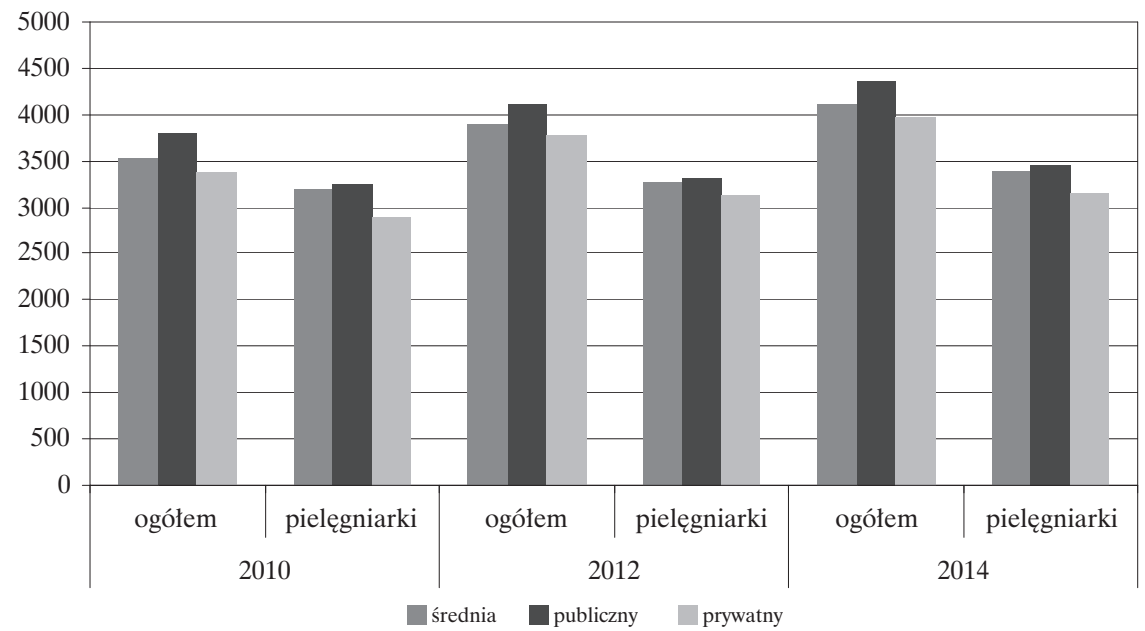

Źródło: jak w tabeli 2.

nieuwzględniania wynagrodzeń tej części populacji pielęgniarek nie pozwala na formułowanie kategorycznych wniosków.

\section{Wynagrodzenia pielęgniarek w zależności od okresu zatrudnienia}

Wydaje się, iż uniwersalną prawidłowością jest wzrost poziomu wynagrodzenia wraz z wydłużaniem się stażu pracy osoby zatrudnionej.

W tabeli 4 i na rysunku 5 przedstawiono poziom przeciętnego wynagrodzenia brutto pracowników zatrudnionych w podmiotach gospodarczych, w których pracuje powyżej 9 osób oraz pielęgniarek, klasyfikując zatrudnionych według kryterium stażu pracy.

Analiza danych przedstawionych na rysunku 5 potwierdza tezę, że zazwyczaj wraz z wydłużaniem się stażu pracy wzrasta poziom przeciętnego miesięcznego wynagrodzenia brutto. Prawidłowość ta obserwowana jest w odniesieniu zarówno do zatrudnionego $\mathrm{w}$ dowolnym podmiocie gospodarczym, jak i pielęgniarek.

Jednak występują także dosyć istotne różnice w wysokości otrzymywanych

Tabela 4. Poziom przeciętnego miesięcznego wynagrodzenia brutto osób pracujących w podmiotach gospodarczych zatrudniających powyżej 9 osób oraz pielęgniarek oraz wynagrodzenia pielęgniarek sklasyfikowanych według stażu pracy w latach 2010-2014 (w PLN)

\begin{tabular}{|l|c|c|c|c|c|c|}
\hline \multirow{2}{*}{ Staż pracy } & \multicolumn{2}{|c|}{$\mathbf{2 0 1 0}$} & \multicolumn{2}{c|}{$\mathbf{2 0 1 2}$} & \multicolumn{2}{c|}{$\mathbf{2 0 1 4}$} \\
\cline { 2 - 7 } & ogółem & pielęgniarki & ogółem & pielęgniarki & ogółem & pielęgniarki \\
\hline Do 1,9 roku & 2464,78 & 2609,00 & 2735,43 & 2641,84 & 2959,78 & 2675,65 \\
\hline $2-4,9$ & 2974,78 & 2793,11 & 3259,55 & 2942,70 & 3475,49 & 2925,36 \\
\hline $5-9,9$ & 3475,59 & 2819,33 & 3802,50 & 2926,23 & 3991,87 & 3153,85 \\
\hline $10-14,9$ & 3832,89 & 3058,61 & 4236,80 & 3167,28 & 4352,05 & 3180,94 \\
\hline $15-19,9$ & 3862,63 & 3218,37 & 4339,73 & 3307,38 & 4608,48 & 3435,38 \\
\hline 20 lat i więcej & 3719,30 & 3275,59 & 4068,51 & 3338,51 & 4314,41 & 3475,95 \\
\hline
\end{tabular}

Źródło: jak w tabeli 2. 
Rysunek 5. Poziom przeciętnego wynagrodzenia brutto ogółem oraz pielęgniarek sklasyfikowanych według stażu pracy w latach 2010-2014 (w PLN)

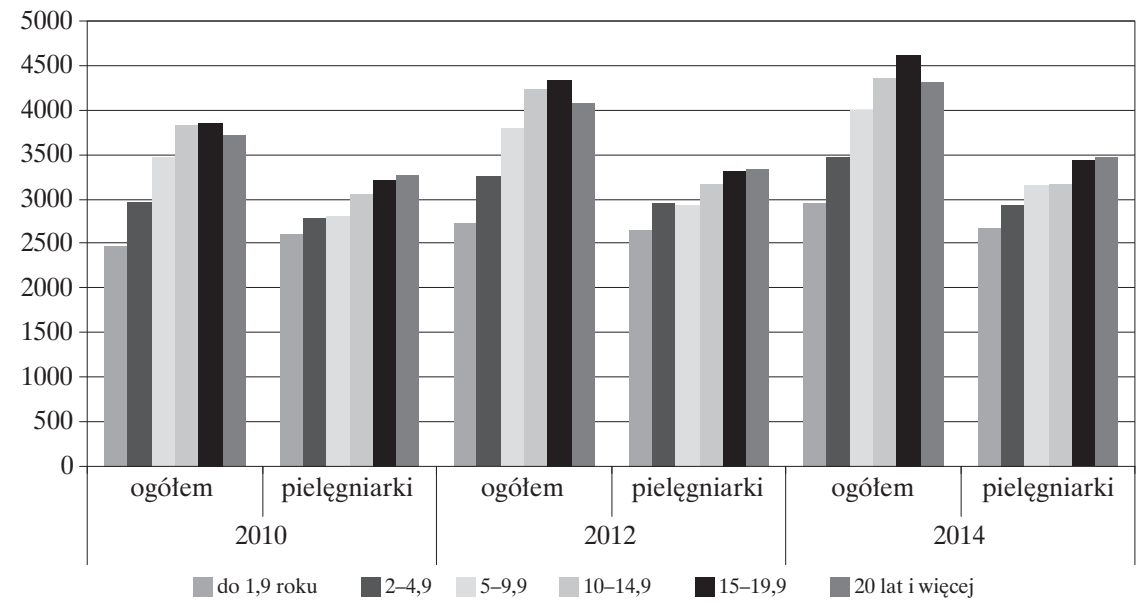

Źródło: jak w tabeli 2.

wynagrodzeń: o ile dłuższy staż pracy zatrudnionego $\mathrm{w}$ dowolnym podmiocie gospodarczym pociąga za sobą zazwyczaj znaczące przyrosty poziomu wynagrodzenia (ok. 500 PLN przy przechodzeniu do grupy o dłuższym stażu zawodowym), o tyle w przypadku pielęgniarek te wzrosty są albo niewielkie, albo w ogóle nie występuja. Zjawisko to było wyraźnie widoczne zwłaszcza w 2014 roku. Wraz z wydłużeniem stażu zawodowego wynagrodzenie zatrudnionego $\mathrm{w}$ dowolnym podmiocie gospodarczym wzrosło z ok. 3000 PLN do 4600 PLN (o ponad 50\%), a w grupie pielęgniarek nastąpił jedynie wzrost z 2675 PLN do 3475 PLN (o ok. 30\%).

Widoczne jest jeszcze jedno niepokojące zjawisko, zachodzące w ostatnich latach. W roku 2010 rozbieżność między poziomem miesięcznego wynagrodzenia brutto ogółem oraz pielęgniarek nie była bardzo duża (największa dla przedziału zatrudnienia 10-15 lat - wynosiła poniżej 800 PLN na niekorzyść pielęgniarek, a w przedziale pracowników o stażu pracy do 2 lat - nawet wyższe wynagrodzenie otrzymywały pielęgniarki). W 2014 roku nastąpiła znacząca dywersyfikacja poziomu wynagrodzeń ogółu zatrudnionych w podmiotach gospodarczych i pielęgniarek: już przy stażu pracy poniżej 2 lat pielegniarka otrzymywała o ponad 200 PLN niższe miesięczne wynagrodzenie brutto, a wraz z wydłużaniem się czasu zatrudnienia ta rozbieżność w szybkim tempie rosła i wynosiła dla zatrudnionych w okresie: $10-15$ i 15-20 lat już ponad 1150 PLN.

\section{Wynagrodzenia pielęgniarek w zależności od wieku}

W tabeli 5 i na rysunku 6 przedstawiono poziom przeciętnego miesięcznego wynagrodzenia brutto pracowników należących do różnych grup wiekowych.

Rozpiętość w poziomie przeciętnego miesięcznego wynagrodzenia brutto pracowników ogółem w różnym wieku była w analizowanym okresie znaczna: w roku 2010 wahała się między ok. 2300 PLN a 5200 PLN (różnica 2900 PLN), w roku 2012 - między 2500 PLN a 6200 PLN (różnica 3700 PLN), a w roku 2014 - między 2650 PLN a 6200 PLN (różnica 3550 PLN). Najniższe średnie wynagrodzenie otrzymywały osoby najmłodsze, w wieku do 24 lat, natomiast najwyższe średnie wynagrodzenie otrzymywały osoby w wieku 65 i więcej lat.

Natomiast rozpiętości w przeciętnych miesięcznych wynagrodzeniach brutto pielęgniarek w różnym wieku nie były tak znaczne; w roku 2010 mieściły się w przedziale: 2500-3300 PLN (różnica 800 PLN), w roku 2012: 2650-3500 PLN (różnica 850 PLN), a w roku 2014 zawierały się w przedziale: 2700-4150 PLN (różnica 1450 PLN). Najniższe wynagrodzenia otrzymywały najmłodsze pielęgniarki, natomiast najwyższe wynagrodzenie - dopiero $\mathrm{w}$ roku 2014 - najstarsze, liczące 65 lat i więcej. 
Tabela 5. Poziom przeciętnego miesięcznego wynagrodzenia brutto ogółem oraz pielęgniarek w zależności od wieku w latach 2010-2014 (PLN)

\begin{tabular}{|l|c|c|c|c|c|c|}
\hline \multirow{2}{*}{ Wiek } & \multicolumn{2}{|c|}{2010} & \multicolumn{2}{c|}{2012} & \multicolumn{2}{c|}{2014} \\
\cline { 2 - 7 } & ogółem & pielęgniarki & ogółem & pielęgniarki & ogółem & pielęgniarki \\
\hline do 24 lat & 2305,32 & 2499,91 & 2507,95 & 2648,43 & 2652,63 & 2684,45 \\
\hline $25-34$ & 3339,80 & 2967,91 & 3641,32 & 3003,52 & 3787,24 & 3097,11 \\
\hline $35-44$ & 3871,25 & 3203,09 & 4314,33 & 3283,33 & 4548,86 & 3418,28 \\
\hline $45-54$ & 3571,60 & 3236,94 & 3925,63 & 3307,84 & 4197,50 & 3453,17 \\
\hline $55-59$ & 3721,71 & 3295,62 & 3919,46 & 3336,25 & 4072,54 & 3420,55 \\
\hline $60-64$ & 4452,36 & 3012,11 & 4714,96 & 3484,71 & 4597,17 & 3389,64 \\
\hline 65 i więcej & 5231,99 & 2288,40 & 6235,56 & 3339,61 & 6166,28 & 4161,43 \\
\hline
\end{tabular}

Źródło: jak w tabeli 2.

Rysunek 6. Poziom przeciętnego miesięcznego wynagrodzenia brutto ogółem oraz pielęgniarek w zależności od wieku w latach 2010-2014 (w PLN)

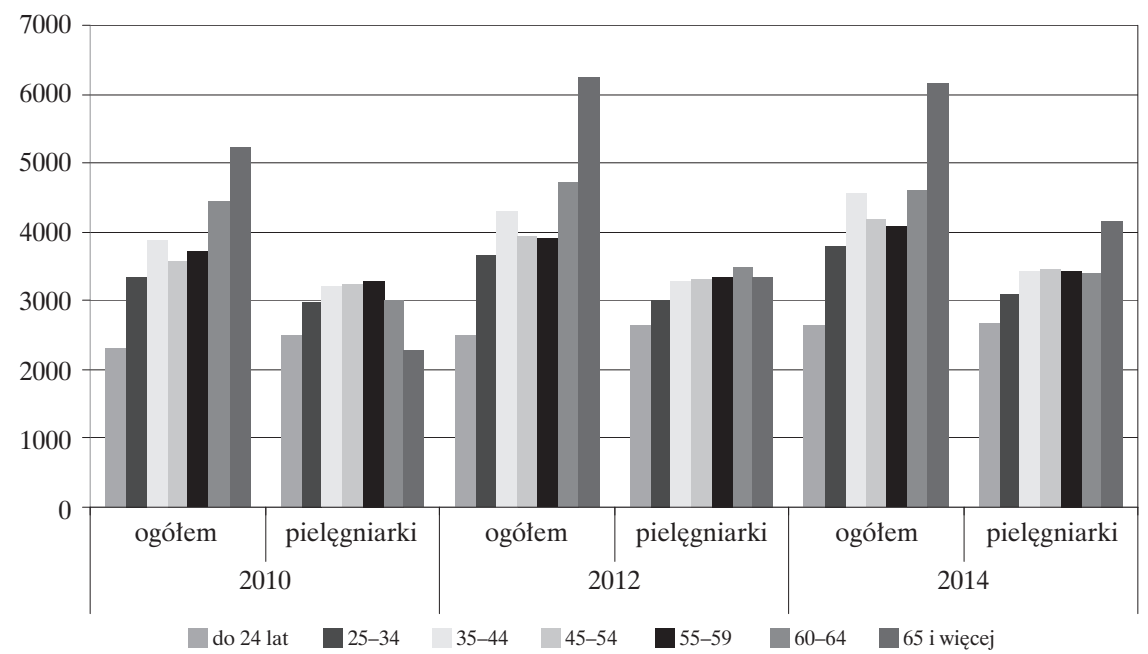

Źródło: jak w tabeli 2.

7. Porównanie poziomu przeciętnych rocznych wynagrodzeń brutto pielęgniarek zatrudnionych w szpitalach z krajów OECD

Organizacja Współpracy Gospodarczej i Rozwoju (Organization for Economic Cooperation and Development, OECD), wśród wielu wskaźników dotyczących systemu ochrony zdrowia, publikuje także zestawienie rocznych wynagrodzeń pielęgniarek zatrudnionych w szpitalach (Health, 2015).
Na rysunku 7 przedstawiono zestawienie przeciętnych rocznych wynagrodzeń brutto pielegniarek zatrudnionych w szpitalach w 29 krajach OECD. Poziom wynagrodzeń wyrażono w USD (według parytetu siły nabywczej - wg PPP).

Analiza danych na rysunku 7 pozwala stwierdzić, że przeciętne roczne wynagrodzenie brutto polskich pielęgniarek zatrudnionych w szpitalach w 2013 roku było jednym $\mathrm{z}$ najniższych $\mathrm{w}$ krajach OECD. Osiągnęło ono poziom nieco poniżej 24 tys. 
Rysunek 7. Przeciętne roczne wynagrodzenie pielęgniarek zatrudnionych $w$ szpitalach $w$ krajach OECD w 2013 roku (lub najbliższym) w USD (wg PPP)

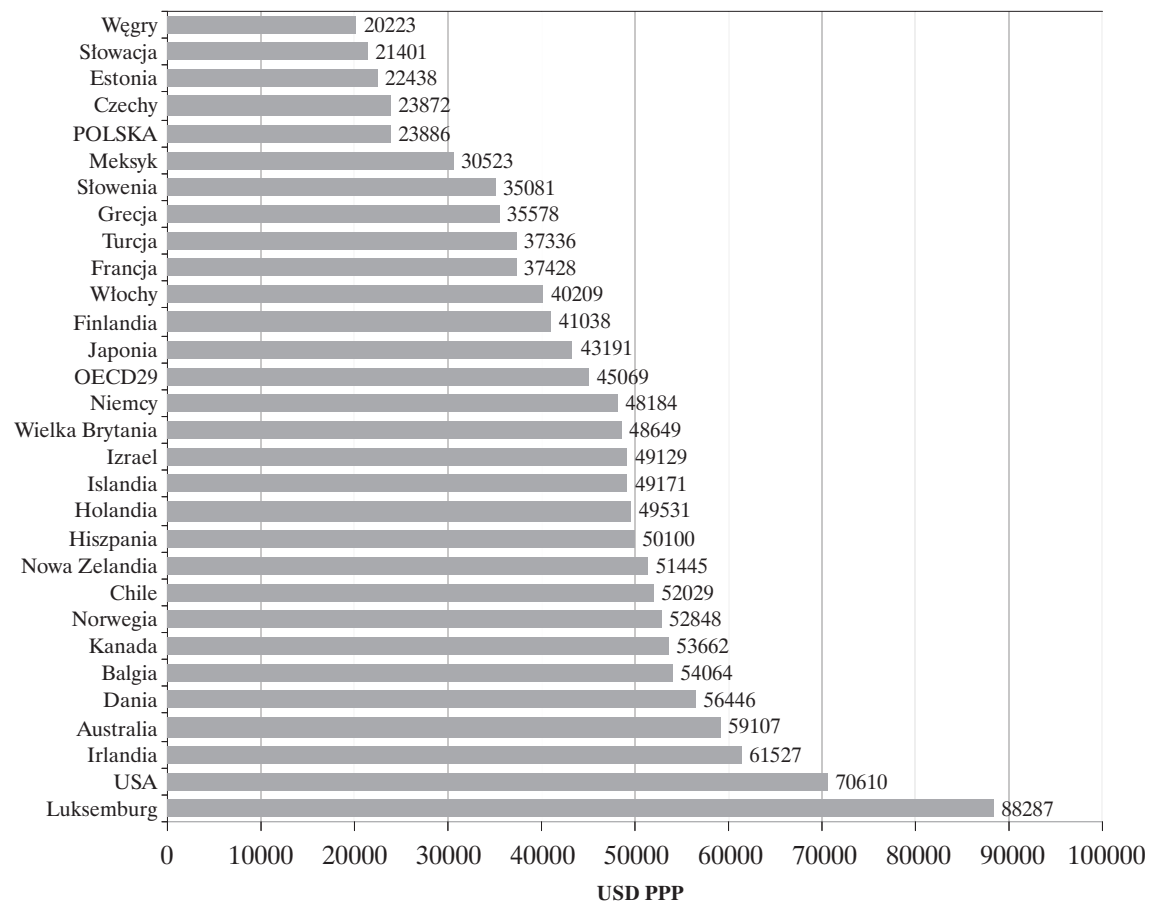

Źródło: Health At a Glance 2015 (2015), tabela 5.21.

USD i uplasowało Polskę na 5. od końca miejscu listy 29 krajów OECD. W gorszej sytuacji materialnej były jedynie pielęgniarki pracujacce w szpitalach w Czechach, Estonii i Słowacji, a w najgorszej - pracujące na Węgrzech.

$\mathrm{Na}$ czele listy, $\mathrm{z}$ poziomem bliskim 90 tys. USD, znalazło się wynagrodzenie pielegniarek pracujacych w szpitalach w Luksemburgu; na kolejnym miejscu znalazło sie wynagrodzenie pielegniarek w USA - ok. 70 tys. USD oraz Irlandii ponad 60 tys. USD.

Zastanawiający jest fakt uplasowania się na odległych pozycjach listy wysoko rozwiniętych krajów europejskich, przeznaczających znaczną część PKB na wydatki na ochronę zdrowia, takich jak: Francja $\mathrm{z}$ przeciętnymi rocznymi płacami brutto dla pielęgniarek 37,5 tys. USD (20. miejsce na liście), Włochy - 40 tys. USD (19. miejsce), czy Niemcy - 48 tys. USD (16. miejsce na liście prezentowanych 29 krajów OECD). Widać zatem, że nawet w krajach przeznaczających w 2013 roku na ochronę zdrowia znacznie większy niż Polska odsetek PKB (Niemcy - 11\%, Francja - 10,9\%, Włochy $-8,8 \%$, a Polska - jedynie $6,4 \%$ ) wynagrodzenia pielegniarek nie kształtowały sie na najwyższym światowym poziomie (Health, 2015).

Porównanie danych dotyczących wynagrodzeń polskich pielęgniarek, a pochodzących z bazy danych OECD i GUS wskazuje na znaczące rozbieżności:

- wg OECD - przecietne miesieczne wynagrodzenie pielęgniarki pracującej w szpitalu w 2013 roku wynosiło ok. 2000 USD, czyli ok. 6200 PLN (w dniu 1.10.2013 kurs USD według tabeli NBP wynosił 3,11 PLN);

- wg GUS - przeciętne miesięczne wynagrodzenie brutto pielęgniarki pracującej w placówce ochrony zdrowia zatrudniającej powyżej 9 osób wynosiło w 2012 roku 3276,61 PLN, a w 2014 roku 3400,31 PLN.

Przedstawione zestawienie danych pochodzacych $\mathrm{z}$ dwóch źródeł pokazuje duże rozbieżności między wynagrodze- 
niem polskich pielęgniarek. Faktem jest, że porównuje się w tym przypadku dwie różne grupy pielęgniarek. Pielęgniarki pracujące w szpitalach (ujęte w danych OECD) być może mają wyższe wynagrodzenia - bo np. są wyższej klasy specjalistkami, zatrudnione są na tzw. kontraktach, mają szanse na wzięcie dużej liczby godzin nadliczbowych. Pielęgniarki objęte badaniami GUS to - oprócz pielęgniarek pracujących w szpitalach - również osoby pracujące w tzw. podstawowej opiece zdrowotnej, niemające często możliwości wzięcia dodatkowych dyżurów, mające czasami niższe kwalifikacje itp. Różne były również liczebności badanych grup.

Słabą stroną przedstawionej pracy jest to, że wykorzystuje ona jedyne dostępne i powtarzalne badania przeprowadzane przez GUS. Niestety te dane obejmuja jedynie wynagrodzenia pielęgniarek zatrudnionych na podstawie umowy o prace w podmiotach zatrudniających powyżej 9 osób, nie obejmuja zatem np. wynagrodzeń pielęgniarek zatrudnionych w małych placówkach opieki zdrowotnej, prowadzących tzw. indywidualne praktyki pielęgniarskie. Tym samym nie odzwierciedlają pełnego obrazu i rzeczywistej sytuacji w obszarze wynagrodzeń pracowników służby zdrowia Brak pełnych danych wskazuje na potrzebę przeprowadzenia rzetelnych i kompleksowych badań w tym zakresie.

\section{Podsumowanie}

Wysokość wynagrodzenia pielegniarek budzi od wielu lat szereg kontrowersji zarówno w grupie samych zainteresowanych, jak i w całym społeczeństwie. $\mathrm{Na}$ podstawie analizy ostatnich i najbardziej aktualnych danych, pochodzących z badań przeprowadzonych przez GUS, a dotyczących wynagrodzenia osób pracujących w podmiotach gospodarczych zatrudniających powyżej 9 osób wykazano, że zarówno sama wysokość przeciętnego miesięcznego wynagrodzenia pielegniarek, jak i tempo wzrostu tego wynagrodzenia do roku 2014 było jednym $z$ najniższych. W analizowanym okresie (lata 2010-2014) niekorzystne różnice między wynagrodzeniem pielęgniarek a osób zarówno zatrudnionych w gospodarce narodowej, jak i pracujących w podmiotach gospodarczych zatrudniających powyżej 9 osób (ogółem) uległy pogłębieniu. Przeciętne miesięczne wynagrodzenia pielęgniarek (oraz położnych) są jednymi z najniższych $\mathrm{w}$ grupie pracowników zawodów medycznych. Oceniając wzrost wynagrodzeń w pewnym okresie należy porównać tempo wzrostu płac nominalnych z tempem zmian cen dóbr i usług konsumpcyjnych, czyli stopa inflacji. Po uwzglednieniu stopy inflacji wykazano, że szczególnie ciężkim okresem dla sytuacji bytowej pielęgniarek były lata 2010-2012: w tym czasie ich wynagrodzenie brutto wzrosło jedynie o 2,8\%, a ceny dóbr konsumpcyjnych - aż o 8,2\%, nastąpił zatem spadek płacy realnej o ok. 5\%. Natomiast w latach 2012-2014 sytuacja pielęgniarek była nieco korzystniejsza: odnotowano wzrost płac pielęgniarek o 3,8\%, a ceny dóbr konsumpcyjnych wzrosły jedynie o $0,9 \%$, czyli nastapił wzrost płacy realnej o 2,9\%. Powyższe prezentacje zmian płacy realnej pielegniarek pokazuja, że ich żądania wzrostu wynagrodzeń nie sa bezpodstawne. Wraz $\mathrm{z}$ wydłużaniem się stażu pracy wzrasta poziom przeciętnego miesieccznego wynagrodzenia brutto w odniesieniu zarówno do zatrudnionego w dowolnym podmiocie gospodarczym, jak i pielęgniarek. Występują także jednak dosyć istotne różnice w wysokości otrzymywanych wynagrodzeń: o ile dłuższy staż pracy zatrudnionego $\mathrm{w}$ dowolnym podmiocie gospodarczym pociąga za sobą zazwyczaj znaczące przyrosty poziomu wynagrodzenia (ok. 500 PLN przy przechodzeniu do grupy o dłuższym stażu zawodowym), o tyle w przypadku pielęgniarek te wzrosty są albo niewielkie, albo w ogóle nie występują. Zjawisko to było wyraźnie widoczne zwłaszcza w 2014 roku. Przy uwzględnieniu kryterium wieku wykazano również ogólną prawidłowość, że najniższe wynagrodzenia otrzymywały najmłodsze pielęgniarki, natomiast najwyższe wynagrodzenie - dopiero w roku 2014 - pielęgniarki najstarsze, liczące 65 lat i więcej. Różnice te nie były jednak tak wyraźne jak w grupie osób zatrudnionych w innych sektorach.

Zastanawiający jest fakt znacznych różnic danych między danymi pochodzacymi z różnych źródeł (np. OECD i GUS). Przy braku informacji o liczbie osób objętych badaniami oraz braku dostępu do pełnej metodologii badań trudno jest oceniać wiarygodność takich danych. Na pewno konieczne jest przeprowadzenie pełnych badań dotyczących wynagrodzeń pracowników służby zdrowia na reprezentatywnej próbie. 


\section{Bibliografia}

Alameddine, M., Baumann, A., Laporte, A. i Deber, R. (2012). A narrative review on the effect of economic downturns on the nursing labour market: implications for policy and planning. Human Resources for Health, 10:23, http://dx.doi. org.10.1186/1478-4491-10-23

Centralny Rejestr Pielęgniarek i Położnych, arch. nipip.pl/index.php/aktualności/systemy-informatyczne-ochrona-danych-oaobowych/2996-centralnyrejestr-pielegniarek-i-poloznych. (10.11.2016).

Cichońska, D., Banaszewska, A. i Fedorowski, J.J. (2015). Aby pielęgniarka była pielęgniarką (raport). Menedżer Zdrowia, 6-7. Pozyskano z: www.termedia.pl/Aby-pielegniarka-byla-pielegniarka,12,25670,1,0.html (18.08.2016).

Hader, R. (2010). The compensation tumble. Nurs Manage, 41: 26-31.

Hajec, M. (2015). Wynagrodzenia pielegniarek w Polsce, 31.03.2015, Sedlak\&Sedlak. Pozyskano z: http:// wynagrodzenia.pl/artykul/wynagrodzenia-pielegniarek-w-Polsce (20.11.2016).

Health At a Glance 2015 (2015). OECD, www.oecd. org

Interpelacja nr 29353 w sprawie wysokości pensji oraz sposobu przyznawania premii i dodatków w grupie zawodowej pielęgniarek i położnych (2014). Pozyskano z: http://www.sejm.pl/sejm7.nsf/ interpelacje.xsp (29.10.2016)
Poręba, G., Ptaca i praca pielęgniarek, 13.06.2016, Sedlak\&Sedlak. Pozyskano z: http://wynagrodzenia $\mathrm{pl} /$ artykul/placa-i-praca-pielegniarek (20.11.2016).

Prestiż zawodów, komunikat z badań BS/164/2013 (2013). CBOS, Warszawa.

Roczne wskaźniki makroekonomiczne. Pozyskano z: http://stat.gov.pl/wskazniki-makroekonomiczne/ (12.11.2016)

Rocznik Statystyczny RP 2013 (2014). Warszawa: GUS. Rocznik Statystyczny RP 2015 (2016). Warszawa: GUS

Rozporządzenie Ministra Zdrowia w sprawie ogólnych warunków umów. Podwyżki dla pielęgniarek i położnych - pytania i odpowiedzi, Ogólnopolski Związek Zawodowy Pielęgniarek i Położnych. Pozyskano z: http://ozzpip.pl/wp-content/uploads/2015/11/faq_calosc.pdf, (21.11.2016).

Struktura wynagrodzeń wedtug zawodów w październiku 2010 (2012). Warszawa: GUS.

Struktura wynagrodzeń wedtug zawodów w październiku 2012 (2014). Warszawa: GUS.

Struktura wynagrodzeń wedtug zawodów w październiku 2014 (2016). Warszawa: GUS.

Ustawa z dnia 15 lipca 2011 roku o zawodach pielęgniarki i położnej. Dz.U. 2011 Nr 174, poz. 1039.

Zabezpieczenie społeczeństwa polskiego $w$ świadczenia pielegniarek i potożnych, raport Naczelnej Rady Pielęgniarek i Położnych, Naczelna Izba Pielęgniarek i Położnych, maj 2015. 